\title{
Pós-modernidade como gesto de despedida: a "crítica autorreferencial da razão" no pensamento estético nietzschiano:
}

\author{
[Postmodernity as a farewell "gesture": the "self-referential critique of reason" in Nietzsche's \\ esthetic thinking]
}

\section{Nabil Araújo ${ }^{1}$}

\begin{abstract}
This paper is based on considerations by Gianni Vattimo and Jürgen Habermas on Nietzsche's institution of postmodernity as a "farewell" to Western Modernity and to the kind of rationality associated with it. Here we analyze how a "self-referential critique of reason" (Habermas) is actually engendered by Nietzschean aesthetic thought. We thus reconsider the terms in which the postmodern "farewell" itself should be conceived.
\end{abstract}

Keywords: Postmodernity; Nietzschean aesthetics; self-referential critique of reason

Resumo: Partindo das considerações de Gianni Vattimo e de Jürgen Habermas sobre a instauração nietzschiana da pós-modernidade como uma "despedida" à modernidade ocidental e ao tipo de racionalidade a ela associada, este texto analisa o modo pelo qual uma "crítica autorreferencial da razão" (Habermas) é efetivamente engendrada pelo pensamento estético nietzschiano, de modo a reconsiderar os termos pelos quais a própria "despedida" pós-moderna deve ser concebida.

Palavras-chave: Pós-modernidade - estética nietzschiana - crítica auto-referencial da razão

Na introdução a La fine della modernità [O fim da modernidade] (1985), livro que marcou época na discussão acerca da definição de uma "cultura pós-moderna", Gianni Vattimo pondera, de partida, que "a esparsa e nem sempre coerente teorização do pós-moderno" só

\footnotetext{
${ }^{1}$ Professor de Literatura Comparada na Faculdade de Letras da UFMG. E-mail: nabil.araujo@gmail.com
} 
Araújo, N. - Pós-modernidade como gesto de despedida

adquire "rigor e dignidade filosófica" quando posta em relação com as filosofias de Nietzsche e de Heidegger (VATTimo 1985: 9), explicando que "exatamente a noção de fundamento, e de pensamento como fundação e acesso ao fundamento, é radicalmente posta em questão por Nietzsche e por Heidegger" (VATTIMo 1985: 10). Em seu caráter propriamente pós-moderno, esse pôr em questão a noção de fundamento não poderia confundir-se, pois, com uma tentativa de superação da mesma, pelo que se permaneceria prisioneiro da lógica de desenvolvimento própria à modernidade como época "dominada pela ideia da história do pensamento como progressiva 'iluminação', que se desenvolve na base de uma sempre mais plena apropriação e reapropriação dos 'fundamentos"” (VATTIMO 1985: 10). Nietzsche e Heidegger se encontrariam, assim, "no estado, por um lado, de ter que criticamente tomar distância do pensamento ocidental enquanto pensamento do fundamento; por outro lado, contudo, não podem criticar esse pensamento em nome de uma outra, mais verdadeira, fundação" (VATTIMo 1985: 10) - e é justamente nisso que se poderia considerá-los "filósofos da pós-modernidade":

O pós- de pós-moderno indica de fato uma despedida [una presa di congedo] da modernidade que, como quer subtrair-se às suas lógicas de desenvolvimento, e nomeadamente, antes de tudo, à ideia de "superação" crítica em direção a uma nova fundação, busca justamente o que Nietzsche e Heidegger buscaram em sua peculiar relação "crítica" com o pensamento ocidental (VATTIMO 1985: 10-11).

Mas essa "despedida", essa tomada crítica de distância em relação à modernidade, se não conduz a uma nova fundação, se conduz, presume-se, a algo como uma não-fundação, conduz, na verdade, exatamente a quêe? "Trata-se, antes de tudo", explica Vattimo, "de se abrir a uma concepção não-metafísica da verdade, que a interprete não tanto a partir do modelo positivista do saber científico, quanto, por exemplo [...], a partir da experiência da arte e do modelo da retórica"; a "experiência pós-moderna da verdade" afigurar-se-ia, assim, em suma, "uma experiência estética e retórica” (VATTimo 1985: 20).

Em Der philosophische Diskurs der Moderne [O discurso filosófico da modernidade], surgido no mesmo ano em que o livro de Vattimo, e tão ou mais importante do que ele para o debate acerca de um pensamento pós-moderno, Habermas não hesita em tomar Nietzsche como o grande "ponto de inflexão" [Drehscheibe] para a "entrada na pós-modernidade" [Eintritt in die Postmoderne] - a qual, também aí, implica o abandono da tentativa de 
Araújo, N. - Pós-modernidade como gesto de despedida

"superar as cisões da modernidade a partir de suas próprias forças motrizes", isto é, de "talhar o conceito de razão pelo programa de um esclarecimento [Aufkärung] em si mesmo dialético": assim, Nietzsche "renuncia a uma nova revisão do conceito de razão e despedese [verabschiedet] da dialética do esclarecimento" (HABERMAS 1985: 106-105). Essa "Verabschiedung", essa despedida, teria se dado à medida que "Nietzsche utiliza o condutor da razão histórica para no final descartá-la e fincar pé no mito como o outro da razão" (HABERMAS 1985: 107). Habermas tem aí em vista mais especificamente a opus magnum do jovem Nietzsche, Die Geburt der Tragödie [O nascimento da tragédia] (1872), então definida como "uma investigação levada a cabo com meios histórico-filológicos [mit historisch-philologischen Mitteln], que o reconduz às origens, aquém do mundo alexandrino e do mundo romano-cristão, ao 'antigo mundo primordial grego do grandioso, do natural e do humano"” (HABERMAS 1985: 107).

Ora, essa imagem de um investigador que, por uma via "histórico-filológica", recua cronologicamente a ponto de desembocar numa instância mítica originária com a qual então se identifica - de modo a renegar a própria "razão histórica" que a ela lhe dera acesso simplesmente não se sustenta em face de como o próprio Nietzsche define sua empreitada na obra em questão. Ainda no início de Die Geburt, ele determina que "a verdadeira meta de nossa investigação" é dirigida "ao conhecimento do gênio dionisíaco-apolíneo [dionysisch-apollinischen Genius] e de suas obras de arte" (NIETZSCHE 1972: 38); antes disso, já nas primeiras linhas do livro, ele sentencia como um grande ganho para a "ciência estética" a apercepção de que "o desenvolvimento progressivo da arte está ligado à duplicidade do apolíneo e do dionisíaco: de maneira similar àquela pela qual a procriação depende da dualidade dos sexos, em luta contínua e, apenas periodicamente, incidentais reconciliações" (NIETZSCHE 1972: 21); e ainda:

[...] ambos os impulsos [Triebe], tão diversos, caminham aqui lado a lado, quase sempre em aberto conflito um com o outro e incitando-se mutuamente a sempre novos nascimentos mais fortes, para neles perpetuar a luta daquela oposição, sobre a qual a palavra comum "arte" apenas aparentemente lança uma ponte; até que, finalmente, por um miraculoso ato metafísico da "vontade" [Willens] helênica, aparecem emparelhados um com o outro, e nesse emparelhamento geram, por fim, a tão dionisíaca quanto apolínea obra de arte da tragédia ática (NIETZSCHE 1972: 21-22). 
Araújo, N. - Pós-modernidade como gesto de despedida

É justamente esse, afinal, o nascimento [Geburt] referido no nome do livro, e que Nietzsche buscará explorar, então, a título de um problema que "até agora não foi ainda sequer uma vez seriamente levantado, quanto menos, pois, resolvido" (NIETZSCHE 1972: 48); e não apenas do nascimento e do esplendor da tragédia grega - com Ésquilo e Sófocles - falará Nietzsche, mas também de sua morte, que teria sido ocasionada pela ascensão, com Sócrates e Platão, da racionalidade teórico-conceitual na filosofia, sobretudo pela ingerência da mesma no campo da criação dramática, na forma do "aesthetischen Sokratismus", socratismo estético, isto é, daquela "tendência socrática com a qual Eurípides combateu e derrotou a tragédia esquiliana” (NIETZSCHE 1972: 79).

Assim, se de fato Nietzsche promove em seu livro algo como a recondução, sua e de seu leitor, a um mundo primordial grego pré-racional, como quer Habermas, ele não o faz, contudo, como um historiador-filólogo que, procedendo de acordo com o cânone de cientificidade de seu ofício, descobrisse, a certa altura, e como fruto desse seu trabalho, tal substrato originário perdido, deixando-se, então, arrebatar por ele. Essa descida aos subterrâneos imemoriais da cultura ocidental afigura-se, desde o início, desde as primeiras linhas do livro, como uma descida totalmente calculada, com vistas, na verdade, à comprovação de algo que se enuncia desde o início como uma convicção íntima do autor, desprovida, como tal, de lastro "histórico-filológico", cabendo a Nietzsche imbuir da mesma também seu leitor. É assim que um comentarista como Roberto Machado pode afirmar que "O nascimento da tragédia tem dois objetivos principais: a crítica da racionalidade conceitual instaurada na filosofia por Sócrates e Platão; a apresentação da arte trágica, expressão das pulsões artísticas dionisíaca e apolínea, como alternativa à racionalidade" (MACHADO 1997: 11) - a antinomia entre arte trágica e metafísica racional aí significando duas coisas: “por um lado, o 'socratismo estético' subordinou o poeta ao teórico, ao pensador racional, e considerou a tragédia irracional [...]; por outro lado, a arte trágica é a atividade que dá acesso às questões fundamentais da existência, e se constitui, ainda hoje, como antídoto à metafísica racional” (MACHADO 1997: 11-12).

Em estreita conexão com este último ponto estaria o terceiro objetivo do livro, sem o qual, segundo Machado, ele não pode ser inteiramente compreendido: “a denúncia do mundo moderno como uma civilização socrática e a tentativa de descortinar o renascimento 
Araújo, N. - Pós-modernidade como gesto de despedida

da tragédia ou da visão trágica do mundo em algumas manifestações culturais da modernidade" (MACHADO 1997: 13). Também Habermas (1985: 108) salienta que Nietzsche encara a modernidade como "uma última época da muito alongada história de uma racionalização que começa com a dissolução da vida arcaica e a desintegração do mito" e apresenta a arte moderna - epitomada, num primeiro momento, na música de Richard Wagner - "como o medium no qual a modernidade entra em contato com o arcaico".

Detendo-se na natureza da experiência trágica que gostaria de ver repossibilitada em seu próprio tempo, Nietzsche explica que: "O arrebatamento do estado dionisíaco, com sua aniquilação das habituais barreiras e limites da existência, contém, a saber enquanto dura, um elemento letárgico no qual tudo pessoalmente vivenciado no passado imerge"; ver-seiam separados, assim, "através desse abismo do esquecimento", conclui, "o mundo da realidade cotidiana e o da dionisíaca" (NIETZSCHE 1972: 52). Em vista dessa passagem, HABERMAS (1985: 116-117) comenta: "Na experiência estética, a realidade dionisíaca é isolada por um 'abismo do esquecimento' contra o mundo do conhecimento teórico e da ação moral, contra a vida cotidiana".

Mas não é justamente o conhecimento dessa "realidade dionisíaca" tal como avultada na arte trágica justamente aquilo que Nietzsche viabiliza com seu livro? Não é dela, afinal, que em Die Geburt Nietzsche oferece tanto o conceito quanto a teoria? E, ao fazê-lo, não estaria Nietzsche repetindo o próprio gesto de tipo "socrático" pelo qual a subordinação da tragicidade dionisíaco-apolínea à racionalidade teórico-conceitual acarreta o solapamento da primeira pela segunda? Eis, em suma, o grande paradoxo: ao próprio discurso pelo qual Nietzsche tenta então apreender o nascimento da tragédia revela-se imputável a crítica que ele reserva ao discurso responsável pela morte dela - e ele mesmo o reconhecerá.

Na célebre "Versuch einer Selbstkritik" [Tentativa de uma autocrítica] escrita em 1886, quatorze anos depois da publicação de Die Geburt, e que passará a figurar como seu prefácio, Nietzsche o toma, então, a seu livro de juventude, como "ein unmögliches Buch", [um livro impossível], e a esse juízo está ligado o reconhecimento tardio de que a realização do mesmo demandava uma linguagem de que o autor não dispunha à época - 


\section{Araújo, N. - Pós-modernidade como gesto de despedida}

mas a qual poderia, na verdade, ter tentado implementar, não fosse sua falta de ousadia; daí o arrependimento:

O quanto o lamento agora que não tivesse então a coragem (ou a imodéstia?) de permitirme, em todos os aspectos, também uma linguagem própria [eigne Sprache] para tão próprias concepções e façanhas - que eu tentasse expressar penosamente com fórmulas schopenhauerianas e kantianas estranhas e novas valorações que iam desde a base contra $o$ espírito de Kant e Schopenhauer, assim como contra seu gosto! (NIETZsCHE 1972: 13).

Na ausência, pois, da linguagem apropriada, Nietzsche via-se enredado na aporia de, em nome da tragicidade dionisíaco-apolínea, criticar a racionalidade teórico-conceitual - aí epitomada em Kant e Schopenhauer - por meio da própria linguagem da racionalidade teórico-conceitual - aí epitomada nas "fórmulas schopenhauerianas e kantianas" empregadas em Die Geburt; via-se enredado, em outras palavras, na aporia do que HABERMAS (1985: 120) chamará de "selbstbezüglichen Kritik der Vernunft", crítica autorreferencial da razão. E apesar do que Nietzsche admite retrospectivamente em relação a seu livro de juventude, para HABERMAS (id.) "também na maturidade ele não podia alcançar nenhuma clareza acerca do que significa conduzir uma crítica da ideologia [Ideologiekritik] que ataca seus próprios fundamentos" - permanecendo, pois, nesse sentido, permanentemente refém do problema.

Roberto Machado discorda. "Que validade poderá ter uma crítica total da razão feita a partir da razão? Que sentido poderá ter apelar para a razão contra a razão?”, ele se pergunta, e pondera:

Ao levantar essa questão no prefácio de 1886, Nietzsche está mais uma vez, e agora no último período de sua criação filosófica, salientando o antagonismo entre discurso racional e arte trágica. Mas, ao mesmo tempo, e sobretudo, está apontando uma dificuldade para toda filosofia que, como a sua, reivindica uma postura trágica, e, portanto, precisa se expressar numa linguagem adequada a essa visão do mundo: uma linguagem artística e não científica, figurada e não conceitual (MACHADO 1997: 17-18).

Mais do que alcançar plena clareza do problema da "critica autorreferencial da razão", Nietzsche, segundo Machado, já havia mesmo superado o referido problema, isso desde que concluíra, no ano anterior, aquela que, para muitos, permanece como sua obra máxima: Also sprach Zarathustra [Assim falou Zaratustra] (1883-1885). "Não será, a esse respeito, 
Araújo, N. - Pós-modernidade como gesto de despedida

sintomático", indaga-se MACHADO (1997: 18), “que a 'Tentativa de autocrítica' se encerre com um trecho desse livro, sobre a alegria trágica, logo depois de Zaratustra, o personagem central, ser chamado de 'demônio dionisíaco'?" Antes disso, no mesmo texto, Nietzsche alega que o que ele tinha, então, para falar, à época de Die Geburt, não podia, ou melhor, não devia, na verdade, ser falado, mas expresso de outra maneira: tratar-se-ia antes de cantar [singen] e não de falar [reden], pondera NIETZSCHE (1972: 9), e lamenta: "Que pena que não ousei dizer como poeta o que eu tinha então a dizer: eu o poderia ter feito, talvez!” Com vista a essa passagem, Machado enuncia, então, sua tese:

Na obra de Nietzsche, Assim falou Zaratustra [...] é o canto que, em 1886, ele lamentou não ter cantado com seu primeiro livro, significando, a meu ver, sua tentativa mais radical de evitar a contradição que é lutar contra a razão através de uma forma de pensamento submetida à razão; sua tentativa mais radical de seguir a via da arte para levar a filosofia além ou aquém da pura razão; sua tentativa mais radical de fazer a forma de expressão artística criar a temática filosófica trágica (MACHADO 1997:18).

Em se aceitando essa proposição, que avaliação fazer, afinal, da referida "tentativa" nietzschiana? Para Machado não há dúvida: “a posição ímpar do Zaratustra”, ele diz, "está sobretudo em pretender realizar a adequação entre conteúdo e expressão, o que faz dele uma obra de filosofia e, ao mesmo tempo, uma obra de arte, o canto que Nietzsche não cantou em seu primeiro livro, e que permite considerá-lo o ápice de sua filosofia trágica" (MACHADO 1997: 20). Mas encarar o Zaratustra como a encarnação tardia do "canto" que Nietzsche gostaria de ter cantado com Die Geburt e não conseguiu, ou seja, como a plena realização a posteriori de um malogrado projeto de juventude do autor não equivaleria a, em contrapartida, fazer remontar a Die Geburt a determinação a priori do Zaratustra, isto é, a converter o primeiro numa espécie de arte poética à luz da qual, apenas, o segundo se tornaria apreensível e compreensível como pretensa peça maior de uma "filosofia trágica"? Aproximações diversas dos dois livros feitas por Machado não deixam dúvida de que sim. ${ }^{2}$

\footnotetext{
${ }^{2}$ Por exemplo: (1) “O eterno retorno está ligado a um novo canto, a uma nova lira, como é explicitamente dito em 'O convalescente', na terceira parte da obra [Assim falou Zaratustra], retomando, a meu ver, uma ideia de O nascimento da tragédia, que, ao estabelecer a relação entre os componentes da tragédia a partir da poesia lírica, apresenta a palavra e a música como seus componentes apolíneo e dionisíaco e salienta a presença da música nessa relação" (MACHADO 1997: 24); (2) "O sentido do Zaratustra como tragédia pode ser esclarecido a partir da problemática do apolíneo e do dionisíaco, tal como Nietzsche a vê. O nascimento da tragédia expunha o duplo 'milagre' grego criador da epopeia e da tragédia a partir do deus brilhante, luminoso, solar, 
Araújo, N. - Pós-modernidade como gesto de despedida

Com Assim falou Zaratustra, "a dicotomia arte-filosofia" que Nietzsche "denunciou em $O$ nascimento da tragédia, com a crítica ao socratismo, e denunciará na 'Tentativa de autocrítica' como estando presente no estilo conceitual de seu primeiro livro", conclui Machado, "é agora neutralizada pelo projeto de fazer da poesia o meio de apresentação de um pensamento filosófico não conceitual e não demonstrativo” (MACHADO 1997: 22-23). $\mathrm{Na}$ verdade não, quando se pensa que o advento do Zaratustra como "tragédia nietzschiana" não elimina, não apaga, não anula Die Geburt como discurso sobre a tragédia, encontrando mesmo, ao invés, nesse discurso teórico-conceitual, sua condição de possibilidade como tal. Se Die Geburt, discurso teórico-conceitual sobre a tragédia - sem ser ele próprio tragédia -, permanece, assim, como aquilo que dá a ler o Zaratustra como “tragédia nietzschiana", então, a rigor, a referida dicotomia não se encontra "neutralizada", como quer Machado, mas continua ativa na própria dicotomia entre ambos os livros, entre ambas as obras, a "teórica" e a "trágica", na esfera total da Werk nietzschiana.

A bem da verdade, esse problema já se colocava como tal no âmbito da relação entre Die Geburt e o repertório literário grego para o qual Nietzsche lá se volta: no fim das contas, o grande efeito do livro é mesmo o de nos dar a ler as maiores realizações da tragédia helênica como "tragédias nietzschianas", isto é, manifestações exemplares da tragicidade dionisíaco-apolínea tal como definida por Nietzsche - à guisa, pois, de uma arte poética vinda à tona com séculos e séculos de atraso em relação às próprias criações poéticas de que ela forneceria os princípios. É à luz dessa arte poética, aliás, que se torna plausível a hierarquia crítica pela qual Ésquilo e Sófocles se veem exaltados como verdadeiros e grandes tragediógrafos em detrimento de Eurípedes, considerado "o poeta do

Apolo, que, para dar um sentido à existência através da beleza, a princípio reprime o deus Dioniso, mas, ao notar ser isso impossível, une-se a ele dando origem à arte apolíneo-dionisíaca, que tem em Dioniso seu heroi primitivo: a tragédia. No meu entender, apesar das diferenças entre os dois livros, o grande parentesco de Assim falou Zaratustra com o primeiro livro de Nietzsche se evidencia dramaticamente com Zaratustra, o personagem central, despontando como um heroi apolíneo e, em seguida, percorrendo um caminho que o levará a integrar o lado noturno, tenebroso, da vida, tornando-se dionisíaco. Assim falou Zaratustra é a narração dramática do aprendizado trágico de Zaratustra" (MACHADO 1997: 28-29); (3) "[O] modo como $O$ nascimento da tragédia definia o mito trágico: um acontecimento épico que glorifica o herói combatente, lutador, pela apresentação do sofrimento existente no seu destino e em seus triunfos mais dolorosos. É justamente o que acontece com Zaratustra: um herói a princípio fundamentalmente apolíneo que, no final de um processo de aprendizado, em que deve enfrentar o niilismo em suas várias formas, assume seu destino trágico, isto é, diz sim à vida como ela é, sem introduzir oposição de valores, afirmando poeticamente seu eterno retorno" (MACHADO 1997: 29). 
Araújo, N. - Pós-modernidade como gesto de despedida

socratismo estético" ( $§ 9-12)$; ou se vê exaltada a "deutsche Musik", música alemã, “em seu poderoso curso solar de Bach a Beethoven, de Beethoven a Wagner", como o "despertar gradual do espírito dionisíaco em nosso mundo atual" em detrimento da “cultura da ópera" como "cultura socrática" (§19); ou, mesmo, no que se refere a um período anterior ao do próprio nascimento da tragédia, se vê exaltado o lírico Arquíloco como "belicoso servidor das Musas" em detrimento do épico Homero, encanecido "artista ingênuo" (§5).

Isso posto, e o problema a ser enfrentado é mesmo o das condições de emergência (se não o da fundamentação), no discurso nietzschiano, desse dar a ler/a ver/a ouvir manifestações artísticas diversas como irrupção estética do dionisíaco no horizonte hegemônico da racionalidade teórico-conceitual ocidental, de modo a transcendê-lo, quiçá a abandoná-lo totalmente.

Habermas observa oportunamente que "Nietzsche não é exatamente original em seu exame dionisíaco da história", que "Dioniso, o deus conspirador do êxtase, da loucura e das metamorfoses incessantes, experimenta uma surpreendente revalorização no primeiro romantismo [alemão]", já que, "como o deus vindouro, podia atrair para si esperanças de redenção" (HABERMAS 1985: 113-114). Apoiando-se, quanto a isso, em Der kommende Gott. Vorlesungen über die neue Mythologie [O deus vindouro. Lições sobre a nova mitologia] (1982) de Manfred Frank, Habermas explica:

Com Sêmele, uma mulher mortal, Zeus gerou Dioniso, que é perseguido, com cólera divina, por Hera, esposa de Zeus, e levado, por fim, à loucura. Desde então, Dioniso vagueia com um bando selvagem de sátiros e bacantes pelo Norte da África e Ásia Menor, um "deus estrangeiro", como diz Hölderlin, que precipita o Ocidente na "noite dos deuses" deixando para trás somente o dom do êxtase. Mas Dioniso deve regressar algum dia, renascer através dos mistérios e livre da loucura. Dioniso se diferencia de todos os outros deuses gregos como o deus ausente, cujo retorno ainda está por acontecer. O paralelo com Cristo se apresenta: também este morreu e deixou para trás, até o dia de seu regresso, pão e vinho. É verdade que Dioniso tem a particularidade de resguardar, mesmo em seus excessos cultuais, aquela reserva de solidariedade social, por assim dizer, que no Ocidente cristão foi perdida junto com as formas arcaicas da religiosidade. Assim, Hölderlin associa ao mito de Dioniso aquela peculiar figura de interpretação da história que poderia conduzir a uma expectativa messiânica e que se manteve ativa até Heidegger. O Ocidente permanece, desde seus primórdios, na noite da ausência dos deuses ou do esquecimento do Ser; o deus do futuro restaurará as forças perdidas da origem; e o deus iminente torna sensível sua chegada mediante sua ausência dolorosamente trazida à consciência, mediante a "suprema distância"; ao permitir aos desamparados sentirem sempre mais urgentemente o 
Araújo, N. - Pós-modernidade como gesto de despedida

que lhes foi retirado, ele promete ainda mais convincentemente seu retorno: no maior dos riscos avulta, também, aquilo que salva [das Rettende] (HABERMAS 1985: 113-114).

Perguntando-se, então, "por que Nietzsche se distancia desse pano de fundo romântico", Habermas conclui que a chave para a resposta é oferecida pela "comparação entre Dioniso e Cristo, que não apenas Hölderlin faz, mas é feita por Novalis, Schelling, Creuzer, na recepção do mito no primeiro romantismo como um todo"; e ainda: "Essa identificação do vertiginoso deus do vinho com o deus redentor cristão só é possível porque o messianismo cristão visa a um rejuvenescimento [Verjüngung], mas não a uma despedida [Verabschiedung] do Ocidente" (HABERMAS 1985: 114). A quem visasse, então, não ao "rejuvenescimento", mas à "despedida", essa identificação, infere-se, afigurar-se-ia insustentável.

Chamando a atenção, no prefácio de 1886 a Die Geburt, para o "precavido e hostil silêncio com que o cristianismo é tratado no livro inteiro", Nietzsche não se limitará a simplesmente evitar a referida identificação, estabelecendo, antes, a mais aberta oposição do dionisismo estético por ele professado ao cristianismo - ao ponto mesmo de definir a doutrina dionisíaca como "antichristliche", anticristã (NIETZSCHE 1972: 13) -, já que, a bem da verdade, o cristianismo, verdadeiro prolongamento do socratismo, é que primeiramente teria se erigido em máxima contraposição ao dionisismo estético:

$\mathrm{Na}$ verdade, não existe nenhuma contraposição maior à interpretação-e-justificação puramente estética do mundo tal como ensinada neste livro do que a doutrina cristã, que é e quer ser somente moral, e com suas medidas absolutas, por exemplo já com sua veracidade de Deus, relega a arte, toda arte ao reino da mentira - quer dizer, a nega, a execra, a condena (NIETZSCHE 1972: 19).

À medida que a redescoberta e a revalorização de Dioniso pelo primeiro romantismo alemão encontravam-se eivadas pela identificação do antigo deus com Cristo, é de se supor que Nietzsche, passando deliberadamente ao largo da mediação romântica, tenha encontrado uma outra via de acesso ao "verdadeiro" Dioniso. No prefácio de 1886 a Die Geburt ele dá a entender que essa via não teria sido nem científica (historiográfica, filológica, etc.) nem filosófica ou doutrinária em qualquer sentido, mas aquela de uma iniciação mística nos mistérios dionisíacos, mistérios sobre os quais o autor havia 
Araújo, N. - Pós-modernidade como gesto de despedida

procurado, então, manifestar-se, ainda que sem contar com a linguagem apropriada para isso: "Sim, o que é dionisíaco? Neste livro encontra-se uma resposta para isso - um ‘entendido' [Wissender] fala aí, o iniciado e discípulo de seu deus" (NIETZSCHE 1972: 9); e ainda:

Aqui falava, de todo modo, [...] uma voz estranha, o discípulo de um, ainda, 'deus desconhecido', que no momento se escondia sob o capuz do erudito, sob a gravidade e a rabugice dialética do alemão, mesmo sob os maus modos do wagneriano. (NIETZSCHE 1972: 8-9)

[...] algo como uma alma mística e quase menádica [bacante], que, com tribulação e arbitrariamente, quase indecisa sobre se queria comunicar-se ou esconder-se, como que balbuciava numa língua estranha. (NIETZSCHE 1972: 9).

Voltando, com isso em mente, ao $§ 1$ de Die Geburt, no qual é postulada a existência, na base do fenômeno estético, de dois "impulsos" [Triebe] contrapostos, ligados ao universo do "sonho" [Traum], o primeiro, e ao da "embriaguez" [Rausch], o segundo, respectivamente: o apolíneo e o dionisíaco, é de se ressaltar que Nietzsche alega tomar tais denominações dos próprios gregos, que, segundo ele, "tornam perceptíveis ao perspicaz [dem Einsichtigen] os profundos conhecimentos secretos de sua concepção de arte, não, na verdade, através de conceitos, mas nas figuras penetrantemente claras de seu mundo dos deuses" (NIETZSCHE 1972: 21). Mas a quem, aí, seria reservada a prerrogativa dessa "perspicácia"?

A princípio, poder-se-ia projetar como leitor ideal de Nietzsche o também "iniciado" nos mistérios dionisíacos - e o próprio autor irá reconhecer, em retrospectiva, que seu livro de juventude em larga medida se enuncia "como livro para iniciados, como 'música' para aqueles batizados na música, que desde o começo das coisas estão ligados por experiências artísticas comuns e raras, como signo de reconhecimento para parentes de sangue in artibus [na arte]" (NIETZSCHE 1972: 8). Mas estes, seria preciso admitir, são os que menos precisariam do livro de Nietzsche, supostamente tão "entendidos" quanto o autor na matéria em questão, e para quem, portanto, o livro tenderia a soar como um excesso; é assim que, Nietzsche argumentará, "como seu efeito demonstrou e demonstra, [o livro] também deve saber suficientemente bem procurar seus co-visionários [seine Mittschwärmer] e atraí-los para novos caminhos secretos e espaços de dança" (NIETZSCHE 1972: 8). É junto aos 
Araújo, N. - Pós-modernidade como gesto de despedida

potenciais dionisíacos, pois, que o livro deveria procurar estimular as experiências artísticas comuns aos propriamente "iniciados", não podendo haver, quanto a isso, em vista dessa mediação deliberadamente oferecida como tal, nada como um acesso imediato ao que quer que fosse.

Isso fica suficientemente claro logo no $§ 2$ de Die Geburt, no qual Nietzsche, depois de ter tratado do apolíneo e do dionisíaco "como poderes artísticos que irrompem da própria natureza sem a mediação do artista humano e nos quais os impulsos artísticos daquela primeira e diretamente se satisfazem" (NIETZSCHE 1972: 26), dispõe-se a se aproximar, enfim, dos próprios gregos, "a fim de reconhecer em que grau e em que medida esses impulsos artísticos da natureza foram neles desenvolvidos” (NIETZSCHE 1972: 27) e isso, acrescenta, no sentido de "compreender e apreciar mais profundamente a relação do artista grego com seus arquétipos, ou, segundo a expressão aristotélica, a 'imitação da natureza' [die Nachahmung der Natur]" (NIETZSCHE 1972: 27). Ora, parece bastante significativo que, justamente quando se trata de dar ao não-iniciado compreender e apreciar a arte grega à maneira de um iniciado, Nietzsche se veja compelido a remontar à perspectiva clássica do ars imitatur naturam, de modo a fazer emergir no contraste com a concepção mimética aristotélica, dela demarcando-se opositivamente, sua própria concepção mimética - em vista da qual, em contrapartida, a aristotélica revelar-se-ia terminantemente limitada, e equivocada nesse seu limite.

"Em face desses estados artísticos imediatos da natureza", postula Nietzsche quanto aos impulsos apolíneo e dionisíaco, “todo artista é 'imitador' [ist jeder Künstler 'Nachahmer'], seja, de fato, artista onírico apolíneo ou artista extático dionisíaco, ou, enfim - como por exemplo na tragédia grega -, artista simultaneamente onírico e extático" (NIETZSCHE 1972: 26). Apenas aparentemente e à primeira vista essa afirmação poderia ser tomada como um desdobramento tardio do axioma aristotélico da arte como imitação da natureza, uma vez que se encontra justamente aí problematizada por Nietzsche a noção de "natureza" e, por extensão, da relação do "imitador" com a mesma. Se Aristóteles parece mesmo não perceber nenhum obstáculo, no processo da imitação, entre o imitador e a natureza imitada - tudo transcorrendo naturalmente, por assim dizer, de acordo com aquela propensão alegadamente congênita do homem ao imitar (Cf. Poética, IV, 13) -, para 
Araújo, N. - Pós-modernidade como gesto de despedida

Nietzsche, apoiado em Schopenhauer, é justamente o que tomamos habitualmente por natureza, ou realidade, o que se torna, em seu caráter de aparência, uma espécie de barreira entre o imitador e a verdadeira natureza - o que sugere a analogia com o domínio do sonho.

$\mathrm{Na}$ "bela aparência do mundo do sonho, em cuja produção cada ser humano é artista pleno", pondera Nietzsche, "desfrutamos da compreensão imediata da forma [Gestalt], todas as formas [Formen] nos falam, não há nada inútil ou desnecessário" (NIETZSCHE 1972: 22). Evocando sua própria experiência nesse sentido, Nietzsche afirma que, apesar dessa impressão de uma necessidade da realidade onírica, na "mais elevada existência" da mesma, contudo, tem-se "a transluzente sensação de sua aparência” (NIETZSCHE 1972: 22). E ainda:

O homem filosófico tem mesmo o pressentimento de que também sob essa realidade na qual vivemos e estamos oculta-se uma segunda, totalmente diferente, de que portanto também ela [a primeira] é uma aparência; e Schopenhauer assinalou francamente como o distintivo da aptidão filosófica o dom de figurar [vorkommen], certas vezes, a humanidade e todas as coisas como meros fantasmas ou imagens oníricas (NIETZSCHE 1972: 22-23).

Mas o fato de que, em face da realidade onírica, e apesar da apercepção de sua aparência, escolhamos, não obstante, continuar sonhando, vivenciando-a, pois, como se necessária fosse, testemunha, segundo Nietzsche, "que nossa essência mais profunda, o fundo comum a todos nós, experimenta o sonho com profundo prazer e jubilosa necessidade"; e ainda: "Essa alegre necessidade da experiência onírica também foi expressa pelos gregos em seu Apolo: Apolo, como deus de todas as forças criativas, é ao mesmo tempo o deus divinatório" (NIETZSCHE 1972: 23).

No que chama de "história linguística do povo grego", Nietzsche distinguirá "duas correntes principais" de acordo com aquilo que a língua, em cada uma delas, imitou [nachahmte]: (a) "o mundo da aparência e da imagem" [Erscheinungs- und Bilderwelt], ou (b) "o mundo da música" [Musikwelt] (Ibidem, p. 45). A primeira modalidade de arte linguística Nietzsche enquadra, é certo, na categoria do apolíneo, e, por acréscimo, na célebre categoria schilleriana do "ingênuo" - que traduz a unidade do ser humano com a natureza -, fazendo coincidir ambas as categorias: "Onde quer que nos deparemos com o 
Araújo, N. - Pós-modernidade como gesto de despedida

‘ingênuo’ em arte, temos de reconhecer o máximo efeito da cultura apolínea” (NIETZSCHE 1972: 33). O gênero literário por excelência dessa primeira modalidade seria o épico; o representante máximo da mesma, Homero - "que se porta, como indivíduo, para com essa cultura popular apolínea, como o artista individual do sonho para com a aptidão onírica do povo e da natureza em geral" (NIETZSCHE 1972: 33); e ainda:

A "ingenuidade" homérica é para se entender somente como o triunfo completo da ilusão apolínea: é esta uma ilusão [Illusion] tal como a que a natureza, para a realização de seus propósitos, tão frequentemente emprega. A verdadeira meta é encoberta por uma imagem ilusória [Wahnbild]: para esta estendemos as mãos e a natureza alcança aquela através de nosso engano (NIETZSCHE 1972: 33).

Já a segunda modalidade de arte linguística, aquela da qual se diz que nela a língua imita a música, Nietzsche a enquadra na categoria do dionisíaco (ou do dionisíaco-apolíneo), e vê no gênero lírico sua manifestação por excelência. Mas como, por meio de que expediente, afinal, Nietzsche busca dar a apreender a poesia como imitação linguística da música?

Primeiramente, seria preciso esclarecer de que música aí se trata. Remetendo aos antigos festivais dionisíacos gregos, Nietzsche afirma que neles "irrompia, por assim dizer, um traço sentimental da natureza, como se ela tivesse de soluçar por seu despedaçamento em indivíduos" (NIETZSCHE 1972: 29). Encarnando, à sua maneira, esse terrível lamento, o canto e a gestualidade dos entusiastas de Dioniso, observa Nietzsche, "eram algo novo e inaudito para o mundo greco-homérico: e particularmente a música dionisíaca suscitava nele espantos e horrores" (NIETZSCHE 1972: 29); aí avulta a diferença e a novidade fundamentais da música dionisíaca em face da música que Nietzsche chama apolínea:

Se a música aparentemente já era conhecida como uma arte apolínea, ela o era, a rigor, apenas como batida ondulante do ritmo, cuja força criativa foi desenvolvida para a representação de estados apolíneos. A música de Apolo era arquitetura dórica em tons, mas em tons apenas insinuados, como os que são próprios da cítara. Cautelosamente é mantido à distância como não-apolíneo [unapollinisch] justamente aquele elemento que constitui o caráter da música dionisíaca e, assim, da música em geral, a estremecedora violência do som, a consistente torrente da melodia e o mundo absolutamente incomparável da harmonia. No ditirambo dionisíaco o homem é incitado à máxima intensificação de todas as suas capacidades simbólicas; algo jamais experimentado lança-se à expressão, a destruição do véu de Maia, o sendo-um [Einssein] como gênio da espécie, sim, da natureza. Agora a essência da natureza deve expressar-se simbolicamente; um novo mundo de símbolos é necessário, primeiramente todo o simbolismo corporal, [...] todos os gestos dançarinos dos membros ritmicamente em movimento. Em seguida, crescem as outras

Pandaemonium, São Paulo, v. 16, n. 22, Dez/2013, p. 179-201 
Araújo, N. - Pós-modernidade como gesto de despedida

forças simbólicas, a da música, abruptamente impetuosa, na rítmica, na dinâmica e na harmonia. Para apreender esse desencadeamento conjunto de todas as forças simbólicas, o homem já deve ter alcançado aquele nível de despojamento de si [Selbstentäusserung] que quer expressar-se simbolicamente naquelas forças: o servo ditirâmbico de Dioniso só é compreendido, portanto, por seus iguais! (NIETZSCHE 1972: 29-30).

Mas, se assim o é, como equacionar, afinal, a demanda dionisíaca por "Selbstentäusserung", despojamento/renúncia de si próprio, com aquela enunciação ostensivamente em primeira pessoa, aquela centralidade enunciativa do "eu" que se costuma tomar como traço distintivo do gênero lírico? Não se encontraria mesmo a poesia lírica, nesse sentido, nos antípodas da "música dionisíaca" tal como concebida por Nietzsche?

Aprofundando-se nas condições de nascimento da tragédia grega, Nietzsche remonta, endossando-a, à antiga tradição que toma Homero, o épico, e Arquíloco, o lírico, como os "progenitores e porta-archotes da poesia grega", os únicos que devem ser considerados "naturezas inteiramente originais, das quais continuou manando um rio de fogo sobre toda a posteridade grega" (NIETZSCHE 1972: 38), e esclarece que, no tocante a Arquíloco, "a investigação erudita descobriu que ele introduziu a canção popular [Volkslied] na literatura, e que por causa desse feito lhe compete aquela posição única junto a Homero na apreciação geral dos gregos” (NIETZSCHE 1972: 44). Daí a questão: “O que é, no entanto, a canção popular em contraste com o totalmente apolínico epos?" (NIETZSCHE 1972: 44).

Nietzsche observa que, em relação ao contraste entre Homero e Arquíloco herdado da Antiguidade, "a mais nova estética [die neuere Aesthetik] soube apenas acrescentar interpretativamente que, aqui, ao artista 'objetivo' contrapõe-se o primeiro artista "subjetivo"” (NIETZSCHE 1972: 38). Nietzsche recusa-se, contudo, a reconhecer na alegada subjetividade o traço artístico distintivo da poesia de Arquíloco - e, por extensão, de toda poesia lírica - em face da de Homero; a se tomar Arquíloco como o primeiro artista subjetivo, “de onde, então", indaga-se Nietzsche, "a reverência que demonstrou para com ele, o poeta, precisamente o oráculo délfico, o lar da arte 'objetiva', em tão singulares sentenças?" (NIETZSCHE 1972: 39). Permaneceria, assim, a ser resolvido por "nossa estética" [unsere Aesthetik], o problema "de que modo o 'lírico' é possível como artista 
Araújo, N. - Pós-modernidade como gesto de despedida

[wie der 'Lyriker' als Künstler möglich ist]: ele que, segundo a experiência de todos os tempos, sempre diz 'eu' e canta diante de nós a escala cromática de todas as suas paixões e desejos" (NIETZSCHE 1972: 39). E se Schopenhauer se mostrara até então um guia decisivo para a reflexão estética nietzschiana, nesse ponto Nietzsche dele se demarca opositivamente nos seguintes termos:

Schopenhauer, que não ocultou a dificuldade posta pelo lírico para o exame filosófico da arte, crê ter encontrado uma saída, pela qual não posso sair com ele, conquanto somente a ele, em sua profunda metafísica da música, foi dado em mãos o meio com o qual aquela dificuldade poderia ser definitivamente eliminada: tal como eu, em seu espírito e para sua honra, acredito tê-lo feito aqui (NIETZSCHE 1972: 42).

Nietzsche aí condena, na verdade, a recalcitrância, em Schopenhauer, daquela contraposição do subjetivo e do objetivo que ele próprio recusava-se, então, a aceitar. Indo colher junto a Schiller o testemunho de que se tem "como a condição preparatória do ato de escrever poemas não, digamos, uma série de imagens, com ordenada causalidade dos pensamentos, mas, antes, um estado de ânimo musical [eine musikalische Stimmung]" (NIETZSCHE 1972: 39); juntando a isso, além do mais, o que chama de "o mais importante fenômeno de toda a lírica antiga", isto é, a união, a identidade, tida como naturalmente válida, do lírico com o músico (NIETZSCHE 1972: 39), Nietzsche enuncia, então, nos seguintes termos, sua explicação acerca do poeta lírico:

Ele primeiramente, como artista dionisíaco, é tornado um só com o Uno-primordial [ $U r$ Einen], com sua dor e contradição, e produz a reprodução desse Uno-primordial como música $[\ldots] ;[\ldots]$ esta música torna-lhe novamente visível, como numa imagem onírica alegórica [einem gleichnissartige Traumbilde], sob o efeito apolíneo do sonho. [...] $\mathrm{O}$ artista já renunciou à sua subjetividade no processo dionisíaco: a imagem que agora lhe mostra sua unidade com o coração do mundo é uma cena de sonho [...]. O "eu" do lírico ressoa, pois, a partir do abismo do ser: sua "subjetividade", no sentido dos estetas modernos, é uma fantasia. Quando Arquíloco, o primeiro lírico dos gregos, declara seu amor furioso e, ao mesmo tempo, seu desprezo pelas filhas de Licambes, não é então sua paixão que dança diante de nós em orgiástico frenesi: vemos Dioniso e as Mênades, vemos o ébrio entusiasta Arquíloco mergulhado no sono [...]: e agora Apolo se aproxima dele e o toca com o laurel. O encantamento dionisíaco-musical do dormente lança agora ao redor de si como que centelhas de imagens [Bilderfunken], poesias líricas, que em seu desdobramento máximo se chamam tragédias e ditirambos dramáticos (NIETZSCHE 1972: 39-40). 
Araújo, N. - Pós-modernidade como gesto de despedida

Em vista dessa renúncia total da subjetividade pela qual se mostraria, então, possível, não só a poesia lírica, mas também, e como "desdobramento máximo" [höchste Entfaltung] da mesma, a própria tragédia - o coro trágico revelando-se o elemento pelo qual se consumam a ligação e a identificação entre ambas -; em vista, pois, desse esvaziamento pelo qual o artista "está já liberto de sua vontade individual”, tendo se tornado o "medium através do qual o único sujeito verdadeiramente existente celebra sua redenção na aparência" (NIETZSCHE 1972: 43), não estranha que Nietzsche designe como agente do dificultoso processo mimético em questão não o poeta, ou o dramaturgo, e sim a própria língua [die Sprache]: "Na poesia da canção popular, vemos, portanto, a língua concentrada [angespannt] ao máximo em imitar a música"; e ainda: "a palavra, a imagem, o conceito buscam uma expressão análoga à música e agora sofrem em si a violência da música" (NIETZSCHE 1972: 45). E considerar, assim, em suma, como quer Nietzsche (1972: 46), “a poesia lírica como a fulguração imitadora da música em imagens e conceitos" faz avultar a limitação inerente ao processo mimético em questão:

A poesia do poeta lírico não pode expressar nada que não se encontrava já, em sua mais
prodigiosa universalidade e toda validade, na música que o obrigou ao discurso imagético.
O simbolismo universal da música não pode ser, por esse motivo, de modo algum
completamente alcançado por meio da língua, posto que se refere simbolicamente à
contradição e à dor primordiais no coração do Uno-primordial, simbolizando, portanto,
uma esfera que está acima e antes de toda aparência. Em face dela, toda aparência é, antes,
apenas alegoria: daí que a língua, como órgão e símbolo das aparências, não possa nunca e
em parte alguma virar para fora o âmago da música, mas permanece sempre, tão logo se
envolve com a imitação da música, apenas em contato externo com ela, enquanto o sentido
mais profundo dela não pode ser trazido, com toda eloquência lírica, sequer um passo mais
próximo de nós (NIETZSCHE 1972: 47).

Ora, se isso pode mesmo ser dito do próprio discurso poético em face da música que ele alegadamente imita, o que não dizer, então, do discurso que eventualmente procurasse, por sua vez, apreender metadiscursivamente a criação dionisíaca em suas formas diversas (a da poesia lírica, a da poesia dramática, quiçá a da música)? "Somente à medida que o gênio, no ato da procriação artística, funde-se com aquele artista primordial do mundo, é que ele sabe algo sobre a essência eterna da arte”, sentencia, a propósito, Nietzsche, e arremata: "pois naquele estado ele se assemelha, de modo milagroso, à estranha figura dos contos de fadas que pode revolver os olhos e contemplar-se a si mesma; agora ele é ao mesmo tempo 
Araújo, N. - Pós-modernidade como gesto de despedida

sujeito e objeto, ao mesmo tempo poeta, ator e espectador" (NIETZSCHE 1972: 43-44). Rigorosamente falando, portanto: "todo o nosso conhecimento da arte [Kunstwissen] é, no fundo, completamente ilusório [völlig illusorisches]" (NIETZSCHE 1972: 43).

A despeito dessa sua alegada incognoscibilidade, NIETZSCHE (1972: 20) distinguirá, não obstante, a arte, como "a tarefa suprema e a atividade propriamente metafísica desta vida", sentenciando mesmo que "apenas como fenômeno estético a existência e o mundo são perpetuamente justificados" (NIETZSCHE 1972: 43; 148). Aí se desenha, pois, com toda a força e clareza, aquela saída, aquela "despedida" à modernidade e à racionalidade ocidentais de que falam Vattimo e Habermas ao tomarem Nietzsche como ponto de inflexão para a entrada na pós-modernidade. Assim:

Com Nietzsche a crítica da modernidade renuncia pela primeira vez à retenção de seu conteúdo emancipatório. A razão centrada no sujeito [subjektzentrierte Vernunft] é confrontada com o absolutamente outro da razão. E, como instância contrária à razão, Nietzsche invoca as experiências, retransferidas ao arcaico, de autodesvelamento de uma subjetividade descentrada, liberta de todas as restrições da cognição e da atividade propositada, de todos os imperativos da utilidade e da moral. Aquela "ruptura do princípio de individuação" converte-se na rota de fuga da modernidade. [...] [Nietzsche] arranca o momento racional [Vernunftmoment] que se faz valer na obstinação do domínio radicalmente diferenciado da arte de vanguarda do nexo com a razão teórica e com a razão prática e o aparta no irracional metafisicamente transfigurado (HABERMAS 1985: 117).

Já com Schelling, e à diferença de Hegel, observa HABERMAS (1985: 111), não mais a razão especulativa mas "apenas a poesia pode substituir o poder unificador da religião, tão logo esteja vigente publicamente na forma de uma nova mitologia"; à medida, contudo, que Schelling "estabelece todo um sistema filosófico para chegar a essa conclusão", poder-se-ia dizer que, com ele, é "a própria razão especulativa que se sobrepuja mediante o programa de uma nova mitologia"; Friedrich Schlegel dá um passo além: em suas mãos "a nova mitologia transforma-se de uma expectativa filosoficamente fundamentada numa esperança messiânica" (HABERMAS 1985: 111), sendo que "apenas uma poesia tornada autônoma, purificada dos acréscimos da razão teórica e prática, abre a porta para o mundo dos poderes míticos originários” (HABERMAS 1985: 112). Nietzsche, por sua vez, "prossegue [fortsetzt] a purificação romântica do fenômeno estético de todo acréscimo 
Araújo, N. - Pós-modernidade como gesto de despedida

teórico e moral" (HABERMAS 1985: 116) - mas esse prosseguimento extrapola decisivamente o que se encontrava previsto no pensamento romântico.

De acordo com a síntese oferecida por Habermas de sua investigação do discurso filosófico da modernidade, foi mesmo "a intenção de uma revisão do esclarecimento [Aufklärung] que se serve dos próprios meios do esclarecimento, [que] reuniu os críticos de primeira hora de Kant - Schiller com Schlegel, Fichte com os seminaristas de Tübingen [Hölderlin, Schelling, Hegel]" (HABERMAS 1985: 353). É assim que a nova mitologia sonhada pelos primeiros românticos alemães "deveria restituir uma solidariedade perdida, mas não renegar a emancipação que a redenção pelos poderes míticos originários trouxe também para o homem individualizado em face do deus único" (HABERMAS 1985: 114), o recurso a Dioniso devendo aí tornar acessível "apenas aquela dimensão de liberdade pública na qual as promessas cristãs devem cumprir-se do lado de cá, a fím de que o princípio da subjetividade, a um só tempo aprofundado e autoritariamente levado ao poder pela Reforma e pelo Iluminismo, possa perder sua estreiteza" (HABERMAS 1985: 115). Em contraste com esse intuito meramente revisionista em face do esclarecimento e do princípio da subjetividade, Nietzsche dessubjetiviza totalmente o estético ao incorporá-lo a um disonisíaco, diferentemente daquele dos românticos, francamente anticristão, não só o arrancando, assim, de seu nexo kantiano com a razão, em suas modalidades teórica e prática, mas o convertendo, na verdade, na transfiguração metafísica do irracional; com Nietzsche, em suma: “O estético, como a porta para o dionisíaco, é, antes, hipostasiado no outro da razão" (HABERMAS 1985: 120).

Não apenas "outro da razão", mas o estético dionisíaco se apresentaria mesmo, para Nietzsche, como a própria instância a partir da qual se torna possível uma crítica da razão, do hegemônico impulso "socrático" de conhecimento ou de ciência: no prefácio de 1886 a Die Geburt, Nietzsche pondera que se seu primeiro livro de fato lograra conceber "um novo problema: hoje eu diria que foi o próprio problema da ciência - a ciência pela primeira vez apreendida como sendo problemática, como sendo questionável”, isso só foi possível porque o mesmo se encontrava "colocado no terreno da arte - pois o problema da ciência não pode ser reconhecido no terreno da ciência” (NIETZSCHE 1972: 7). O fato, contudo, é que, num cenário como esse, no qual os critérios de 
Araújo, N. - Pós-modernidade como gesto de despedida

problematização/questionamento da racionalidade científica devem ser de ordem exclusivamente estética, enraizados num terreno estético em completa ruptura com os terrenos da razão teórica e da razão prática, Nietzsche, como observa Habermas, se vê terminantemente impedido de legitimar tais critérios,

[...] porque transpõe as experiências estéticas ao arcaico, porque não reconhece a faculdade crítica de valoração agudizada no trato com a arte moderna como um momento da razão que, ao menos processualmente, no procedimento da fundamentação argumentativa, ainda guarda relação com o conhecimento objetivante e com o discernimento moral (HABERMAS 1985: 119-120).

Ora, se a problematização e o questionamento reclamados por Nietzsche de fato se concretizaram, não obstante, em Die Geburt, foi porque se viram formulados, argumentativamente, numa linguagem ainda teórico-conceitual, o que prova que Nietzsche se mantém, aí, ainda, de modo decisivo, do lado de cá da fronteira com esse estado dionisíaco do qual, paradoxalmente, nos fornece o conceito e a teoria. É em vista, aliás, dessa imagem de uma crítica da razão obrigada como tal a proceder racionalmente que Habermas descreve o pensamento nietzschiano como enredado na aporia de uma "crítica autorreferencial da razão".

Mas o que e como seriam, afinal, ou o que e como poderiam ser uma crítica da razão, uma problematização e um questionamento da racionalidade científica, do lado de lá da referida fronteira, isto é, formulados em plena posse do dionisíaco, ou, melhor dizendo, em plena possessão pelo mesmo? Roberto Machado, que se inclina a ver, ele próprio, no Zaratustra, a consumação de um discurso filosófico genuinamente possuído pelo dionisíaco, nos oferece, contudo, tardiamente, parafraseando uma cena d'As bacantes de Eurípedes, quiçá a melhor, de todo modo a mais impressionante ilustração de como o estado de possessão dionisíaca pareceria antes excluir definitivamente qualquer possibilidade de problematizar ou de questionar o que quer que seja:

Mas a melhor ilustração da perda da consciência característica do êxtase, do entusiasmo, do enfeitiçamento dionisíaco é o comportamento de Agave - filha de Cadmo, fundador de Tebas, e irmã de Sêmele, mãe de Dioniso - quando seu filho Penteu, culpado por querer contemplar aquilo que não é permitido ver quando não se é bacante, vai observar as bacantes sem que elas notem, mas o deus as faz descobri-lo e enfurecer-se contra ele. Penteu, acariciando o rosto de sua mãe, pede-lhe que se apiede dele e não o sacrifique.

Pandaemonium, São Paulo, v. 16, n. 22, Dez/2013, p. 179-201 
Araújo, N. - Pós-modernidade como gesto de despedida

Agave, em delírio, "pondo muita espuma pela boca e revirando os olhos desvairadamente, como se Baco a possuísse", não o ouve, esquarteja-o, ajudada por suas duas irmãs, e lança os restos de seu corpo em todas as direções. Depois, toma a cabeça, que ela imagina ser a cabeça de um leão, e a leva em procissão para Tebas, espetada em seu tirso, mostrando-a pelo caminho. Em Tebas, ela a entrega a seu pai, Cadmo, que se lamenta com essas palavras bem elucidativas da antinomia entre a consciência apolínea e o delírio dionisíaco: "Quando recuperardes vossa lucidez sofrereis atrozmente vendo o vosso feito! E se deveis permanecer até o fim nesse estado, se a felicidade vos abandonou, ao menos ignorais vossa desventura!" (MACHADO 2006: 214-215).

Nada de problematização, nada de questionamento, nenhum discurso, enfim, do lado de lá do dionisíaco: apenas, a exemplo da bacante Agave, o terrível silêncio de um sujeito extático, delirante, completamente alienado de si mesmo - portanto, de um não-sujeito. E se o estético deve mesmo ser identificado com essa não-subjetividade dionisíaca, como quer Nietzsche, então será preciso necessariamente inverter a relação entre problematização/questionamento da racionalidade cognoscente, por um lado, e o estéticodionisíaco, por outro: não é o estar sediado neste último que torna possíveis aqueles, mas, ao contrário, uma certa problematização, um certo questionamento da racionalidade cognoscente dita "socrática", mais especificamente na modalidade da crítica estéticoliterária - seja em sua perspectiva mimética clássica, de linhagem platônico-aristotélica, seja na perspectiva subjetiva moderna, de linhagem kantiana -, que dão a ver, em Nietzsche, o estético-dionisíaco como "outro da razão".

Avulta, aqui, a oportunidade para uma compreensão renovada do que Habermas chama de "crítica autorreferencial da razão". Por não haver crítica arracional ao que quer que seja, não haveria, a rigor, crítica da razão que não assumisse, em sua gênese mesma, a forma de uma crítica autorreferencial, tudo se passando, no mais das vezes, como se a Razão se voltasse contra si mesma, e em nome da própria Razão. Bastaria, contudo, analisar mais detidamente esse movimento de "voltar-se contra si mesma" de uma Razão unitária, para se perceber que ali, para além de todo possível revisionismo, encontrar-seiam em disputa concepções diversas e mutuamente excludentes de racionalidade cognoscente, e que apenas pelo efeito homogeneizante e naturalizador acarretado pela vitória e institucionalização de alguma dessas concepções em detrimento das demais é que se firmaria, sempre a posteriori, a visão de um reajustamento “da" Razão por "si mesma”. É assim que a querela do fundamento - que avulta, na modernidade, antes de tudo no 
Araújo, N. - Pós-modernidade como gesto de despedida

terreno da crítica estética - pode ser permanentemente ressignificada nos termos de uma “história do pensamento como progressiva 'iluminação', que se desenvolve na base de uma sempre mais plena apropriação e reapropriação dos "fundamentos"' (Vattimo), isto é, nos termos de uma história da razão como dialética progressiva do esclarecimento (Habermas).

Ora, também em Nietzsche tudo se passa, a princípio, como se "a" razão se voltasse contra si mesma, num gesto de autorreajustamento dialético: a fim de dar a "compreender" e "apreciar" a arte grega como deve ser, ele remonta ao axioma aristotélico da "imitação da natureza", ao modo como o mesmo pareceria sintetizar racionalmente a própria natureza humana, essencialmente "imitadora", para então, apoiando-se em Schopenhauer contra Aristóteles, desmascarar a pretensa imitação da natureza em Homero e em toda "cultura apolínea" como produção de imagens ilusórias que antes encobrem do que reproduzem a "verdadeira" natureza; mas também, num segundo momento do mesmo gesto, jogando Schopenhauer contra si mesmo (enquanto evoca Schiller), dele demarcar-se opositivamente naquilo em que se revela, ainda, tributário do subjetivismo estético modernamente desenvolvido na esteira de Kant. O aristotelismo e o kantismo em crítica estético-literária passam a figurar, aí, como nada mais do que máscaras distintas do mesmo e único socratismo estético a querer impor um fundamento racional àquilo que então se enuncia como a própria ausência de qualquer fundamento, o fenômeno estético, e que agora, finalmente, é dado a ver como tal.

É nesse sentido, pois, bem entendido, que o pensamento nietzschiano há de se deixar compreender, como quer Vattimo, como um "tomar distância do pensamento ocidental enquanto pensamento do fundamento", sem que isso seja feito "em nome de uma outra, mais verdadeira, fundação". Die Geburt só escapa daquilo que, na "crítica autorreferencial da razão" em Nietzsche, Habermas enxerga como uma incontornável aporia, ao ser tomado como a própria performance - gesto permanentemente diferido - ao invés de como a forma consumada, dessa "presa di congedo" (Vattimo), dessa "Verabschiedung" (Habermas) nietzschiana à modernidade e à racionalidade ocidentais, dessa "despedida", enfim, à guisa de um responder a questão do fundamento, a um só tempo contraaristotelicamente e contra-kantianamente, em direção a um pretenso não-fundamento (sem que nunca se possa dizer tê-lo finalmente alcançado). 
Araújo, N. - Pós-modernidade como gesto de despedida

\section{Referências bibliográficas}

HABERMAS, Jürgen. Der philosophische Diskurs der Moderne: zwölf Vorlesungen. Frankfurt am Main: Suhrkamp, 1985.

MACHADO, Roberto. O nascimento do trágico: de Schiller a Nietzsche. Rio de Janeiro: Jorge Zahar, 2006

MACHADO, Roberto. Zaratustra: tragédia nietzschiana. Rio de Janeiro: Jorge Zahar, 1997.

NIETZSCHE, Friedrich. Die Geburt der Tragödie. Oder: Griechenthum und Pessimismus [1872]. In: Nietzsche Werke: Kritische Gesamtausgabe. III, 1. Hg. von G. Colli und M. Montinari. Walter de Gruyter: Berlin/New York, 1972.

VATtiMO, Gianni. La fine della modernità: nichilismo ed ermeneutica nella cultura post-moderna. Milano: Garzanti, 1985.

recebido em 01/08/2013

aceito em 02/09/2013 